\title{
FNBP1 wt Allele
}

National Cancer Institute

\section{Source}

National Cancer Institute. FNBP1 wt Allele. NCI Thesaurus. Code C97541.

Human FNBP1 wild-type allele is located in the vicinity of 9q34 and is approximately 156 $\mathrm{kb}$ in length. This allele, which encodes formin-binding protein 1 , is involved in both actin remodeling and endocytosis. A chromosomal translocation $\mathrm{t}(9 ; 11)(\mathrm{q} 34 ; \mathrm{q} 23)$ of this gene and the MLL gene is associated with rare cases of acute myelogenous leukemia. 